
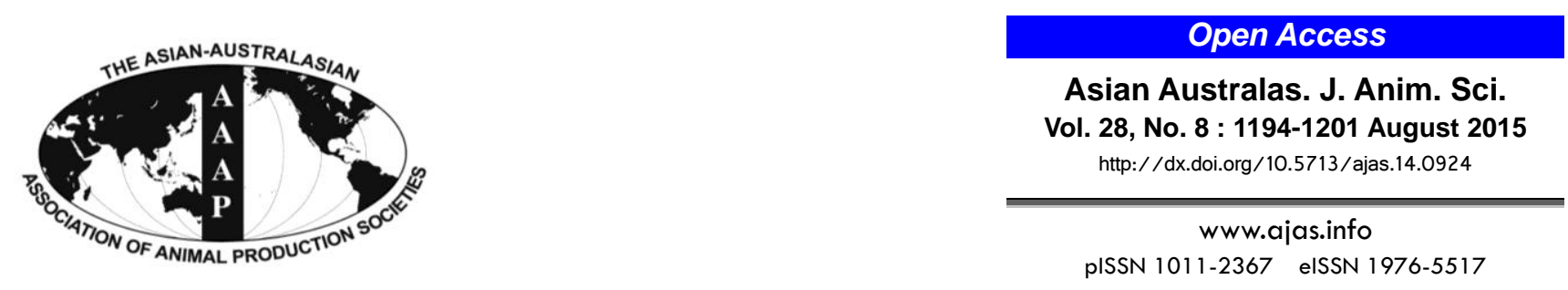

\title{
Consumption of Oxidized Soybean Oil Increased Intestinal Oxidative Stress and Affected Intestinal Immune Variables in Yellow-feathered Broilers
}

\author{
Fangfang Liang, Shouqun Jiang ${ }^{1}$, , Yi Mo ${ }^{2}$, Guilian Zhou ${ }^{1}$, and Lin Yang \\ College of Animal Science, South China Agricultural University, Guangzhou 510642, China
}

\begin{abstract}
This study investigated the effect of oxidized soybean oil in the diet of young chickens on growth performance and intestinal oxidative stress, and indices of intestinal immune function. Corn-soybean-based diets containing $2 \%$ mixtures of fresh and oxidized soybean oil provided 6 levels $\left(0.15,1.01,3.14,4.95,7.05\right.$, and $\left.8.97 \mathrm{meqO}_{2} / \mathrm{kg}\right)$ of peroxide value (POV) in the diets. Each dietary treatment, fed for $22 \mathrm{~d}$, had 6 replicates, each containing 30 birds $(n=1,080)$. Increasing POV levels reduced average daily feed intake (ADFI) of the broilers during $\mathrm{d} 1$ to 10 , body weight and average daily gain at $\mathrm{d} 22$ but did not affect overall ADFI. Concentrations of malondialdehyde (MDA) increased in plasma and jejunum as POV increased but total antioxidative capacity (T-AOC) declined in plasma and jejunum. Catalase (CAT) activity declined in plasma and jejunum as did plasma glutathione S-transferase (GST). Effects were apparent at POV exceeding $3.14 \mathrm{meqO}_{2} / \mathrm{kg}$ for early ADFI and MDA in jejunum, and POV exceeding $1.01 \mathrm{meqO} / \mathrm{kg}$ for $\mathrm{CAT}$ in plasma and jejunum, GST in plasma and T-AOC in jejunum. Relative jejunal abundance of nuclear factor kappa B (NF- $\mathrm{B}$ ) P50 and NF-kB P65 increased as dietary POV increased. Increasing POV levels reduced the jejunal concentrations of secretory immunoglobulin A and cluster of differentiation (CD) 4 and CD8 molecules with differences from controls apparent at dietary POV of 3.14 to $4.95 \mathrm{meqO}_{2} / \mathrm{kg}$. These findings indicated that growth performance, feed intake, and the local immune system of the small intestine were compromised by oxidative stress when young broilers were fed moderately oxidized soybean oil. (Key Words: Oxidized Soybean Oil, Yellow-feathered Broilers, Oxidative Stress, Intestinal Immunity)
\end{abstract}

\section{INTRODUCTION}

Dietary lipids provide an important high density source of energy to increase the metabolizable energy of poultry diets. The high content of unsaturated fatty acids in vegetable oils makes them prone to oxidation with the generation of lipid peroxides, especially when they are used for animal production in hot climates. Lipid peroxides with complex components can damage macromolecules, such as DNA, proteins, and membrane lipids. Some components of

\footnotetext{
* Corresponding Author: Shouqun Jiang. Tel: +86-20-61368865, Fax: +86-20-38765373, E-mail: jsqun3100@ hotmail.com

1 Guangdong Public Laboratory of Animal Breeding and Nutrition, Institute of Animal Science, Guangdong Academy of Agricultural Sciences, Guangzhou 510640, China.

2 Guangxi Research Center for Population and Family Planning, Nanning 530021, China.

Submitted Dec. 9, 2014; Revised Feb. 2, 2015; Accepted Feb. 16, 2015
}

lipid peroxides, for example, 4,5(E)-epoxy-2(E)-heptenal (EH) can react with L-lysine and damage proteins (Rosario and Hidalgo, 1994). 4,5-epoxy-2-alkenals can react with phenylalanine and cause strecker-type degradation of amino acids (Hidalgo and Zamora, 2004). Autoxidized methyl linoleate can decrease DNA synthesis in thymocytes (Oarada et al., 1989). Animals consuming oxidized lipids suffered a wide array of biological consequences, such as decreased feed utilization and performance (Takahashi and Akiba, 1999; Tavárez et al., 2011), oxidative stress and tissue lipid oxidation (Boler et al., 2012; Liu, 2012) and, most strikingly, adverse effects on redox indices and shelf life of meat (Bou et al., 2005; Zhang et al., 2011). This manifested in malondialdehyde (MDA) content (Ringseis et al., 2007; Shafaeizadeh et al., 2011), reduced activities of antioxidant enzymes (David et al., 2010; Zümrüt et al., 2011), and elevated transcript levels of oxidative stressresponsive genes (Varady et al., 2011; Awada et al., 2012). 
The intestinal mucosa is directly exposed to oxidized fatty acids of dietary origin and this tissue readily experiences redox imbalances and oxidative stress after the ingestion of large amounts of oxidized fat (Wijeratne and Cuppett, 2007; Awada et al., 2012). As the first line of defense, the intestines with abundant gut-associated lymphoid tissues (GALTs) and lymphocytes play an important role in immune defense. The immune response in the intestinal tract is complex and is impaired by any damage to the mucosal barrier. When oxidative stress of the intestines caused by oxidized fat occurs, its immune competence and responsiveness may be compromised by the peroxides they contain. The importance and mechanisms of intestinal damage and immune dysfunction in young broiler chicks from partially oxidized lipids are unclear. It was hypothesized that consumption of oxidized soybean oil and oxidative stress in young chicks would compromise the transcripts of cytokines involved in immune reactions and the concentrations of $\mathrm{Ig}$, cluster of differentiation (CD) 4 and CD8 molecules.

\section{MATERIALS AND METHODS}

\section{Preparation of the oxidized soybean oil}

Fresh soybean oil was heated in water baths to $60^{\circ} \mathrm{C}$ for $82 \mathrm{~d}$ with continuous aeration. Peroxide value (POV) was determined in triplicate by the iodometric (visual) endpoint method (ISO. 3960, 2007). The POV of the fresh soybean oil was $7.58 \mathrm{meqO}_{2} / \mathrm{kg}$ and oil, oxidized as above, was $448.49 \mathrm{meqO}_{2} / \mathrm{kg}$. Oxidized oil was mixed with fresh oil to prepare soybean oil with a range of POV (7.58 to 448.50 meqO $\mathrm{O}_{2} / \mathrm{kg}$ ) and stored at $-20^{\circ} \mathrm{C}$ until it was used preparing the diets.

\section{Birds, diets, and management}

Animal management and experimental procedures followed Chinese government guidelines and were approved by the Animal Care and Use Committee of Institute of Animal Science, Guangdong Academy of Agricultural Sciences. A total of 1,080 1-d-old Lingnan yellow male chicks were weighed and randomly assigned to 36 floor pens $(1.35 \mathrm{~m} \times 1.55 \mathrm{~m})$. Each pen contained 30 chicks, and the 36 pens were assigned to the 6 treatment groups, each with 6 replicates. All chicks were fed the same corn-soybean-based diet, but with differing final POV from the addition of $20 \mathrm{~g} / \mathrm{kg}$ of the 6 pre-blended soybean oil mixtures. The final POVs in the diets were 0.15 (basal, control), 1.01, 3.14, 4.95, 7.05, and $8.97 \mathrm{meqO}_{2} / \mathrm{kg}$ mixed feed. Once prepared, the diets were held in sealed containers at $4^{\circ} \mathrm{C}$ for the 22-d duration of the experiment. The nutrient levels (Table 1) were based on the National Research Council requirements for broiler chicks (NRC, 1994). The diets and water were provided ad libitum. All
Table 1. Composition of the diets, as fed basis

\begin{tabular}{|c|c|}
\hline Items & $\%$ \\
\hline \multicolumn{2}{|l|}{ Ingredients } \\
\hline Maize (corn) & 56.5 \\
\hline Soybean meal & 35.3 \\
\hline Fish meal & 2.0 \\
\hline Soybean oil ${ }^{1}$ & 2.0 \\
\hline Limestone & 1.3 \\
\hline Dicalcium phosphate & 1.5 \\
\hline DL-methionine & 0.15 \\
\hline Salt & 0.25 \\
\hline Vitamin-mineral premix ${ }^{2}$ & 1.0 \\
\hline Total & 100 \\
\hline \multicolumn{2}{|l|}{ Chemical composition } \\
\hline Metabolizable energy (MJ/kg) & 12.16 \\
\hline Crude protein & 21.08 \\
\hline Calcium & 1.02 \\
\hline Nonphytate phosphorus & 0.45 \\
\hline Lysine & 1.15 \\
\hline Methionine+cysteine & 0.85 \\
\hline \multicolumn{2}{|c|}{$\begin{array}{l}{ }^{1} \text { Peroxide value of the soybean oil varied between the } 6 \text { diets. } \\
{ }^{2} \text { Supplied per kilogram of diet: vitamin A (trans-retinyl acetate), } 5,000 \\
\text { IU; vitaminD } \\
\text { vitamin } \mathrm{K}_{3}, 0.5 \mathrm{mg} \text {; riboflavin, } 3.6 \mathrm{mg} \text {; niacin, } 30 \mathrm{mg} \text {; pantothenic acid, } \\
10 \mathrm{mg} ; 50 \% \text { choline chloride, } 1,200 \mathrm{mg} \text {; cobalamin, } 10 \mu \mathrm{gg} \text {; biotin, } 0.15 \\
\mathrm{mg} \text {; folic acid, } 0.55 \mathrm{mg} ; \mathrm{FeSO}_{4} \cdot 7 \mathrm{H}_{2} \mathrm{O}, 280.7 \mathrm{mg} ; \mathrm{MnSO}_{4} \mathrm{H}_{2} \mathrm{O}, 266.67 \\
\mathrm{mg} ; \mathrm{CuSO}_{4} 5 \mathrm{H}_{2} \mathrm{O}, 32 \mathrm{mg} ; \mathrm{ZnSO}_{4} \mathrm{H}_{2} \mathrm{O}, 176.47 \mathrm{mg} ; \mathrm{NaSeO}_{3}, 0.15 \mathrm{mg} ; \mathrm{KI} \text {, } \\
0.5 \mathrm{mg} \text {. The carrier was zeolite. }\end{array}$} \\
\hline
\end{tabular}

chicks were weighed on d 1, 10, and 22 and feed consumption per pen was recorded daily. Growth performance was calculated for 1 to $10 \mathrm{~d}$, and 1 to $22 \mathrm{~d}$ as average daily gain (ADG), average daily feed intake (ADFI), and feed intake/gain (F/G), with adjustment for mortality.

\section{Sample collection}

On the morning of $\mathrm{d} 22,2$ chicks per pen were selected at random (other than for excluding outliers in body weight $[\mathrm{BW}])$ for blood sampling and slaughter. Blood $(8 \mathrm{~mL})$ was taken from a wing vein into vacutainers containing ethylenediaminetetraacetic acid. After centrifugation at $2,500 \times \mathrm{g}$ for $10 \mathrm{~min}$ at $4^{\circ} \mathrm{C}$, plasma was stored at $-80^{\circ} \mathrm{C}$. Chicks were then euthanized by approved methods and the jejunum was rapidly excised and flushed with ice-cold phosphate-buffered saline (PBS). About a $2 \mathrm{~cm}$ portion of the jejunum was snap-frozen in liquid nitrogen for RNA isolation. The remaining jejunum was opened length-wide on an ice-cooled surface and the mucosa was gently scraped off and snap-frozen in liquid nitrogen for determining MDA and antioxidant indices. The samples, jejunum and mucosa, were stored at $-80^{\circ} \mathrm{C}$ until analysis.

Mucosal samples and jejunum (100 mg) were homogenized in $1 \mathrm{~mL}$ of $1 \times \mathrm{PBS}(15,000 \mathrm{rpm}$ for $2 \mathrm{~min}$ at 
$\left.4^{\circ} \mathrm{C}\right)$ using a tissue grinder and centrifuged $(5,000 \times g$ for 5 min at $4{ }^{\circ} \mathrm{C}$ ) and held overnight at $-20^{\circ} \mathrm{C}$, subjected to two freeze-thaw cycles and re-centrifuged. The supernatants were assayed immediately or the aliquots were stored at $20^{\circ} \mathrm{C}$ or $-80^{\circ} \mathrm{C}$ and, after thawing, were re-centrifuged, as above. The mucosal supernatants were analyzed for contents of MDA and antioxidant indices were measured in mucosal supernatants and secretory immunoglobulin A (SIgA), CD4, and CD8 molecules were quantified in jejunal extracts.

\section{Malondialdehyde and antioxidant indices in plasma and jejunal mucosa}

The concentrations of MDA in plasma and jejunal mucosa were assayed with thiobarbituric acid method. Activities of total antioxidative capacity (T-AOC), total superoxide dismutase (T-SOD), catalase (CAT), and glutathione S-transferase (GST) were measured colorimetrically at appropriate dilutions in triplicate with assay kits (Nanjing Jiancheng Insititute of Bioengineering, Nanjing, P. R. China).

\section{Immunoglobulin in plasma and jejunum}

The concentrations of immunoglobulin A (IgA) and $\mathrm{IgG}$ in plasma and SIgA in jejunal extracts were measured colorimetrically, through the antigen-antibody reaction, instrument measured absorbance in the $450 \mathrm{~nm}$ wavelength with enzyme-linked immunosorbent assay (ELISA) kits (Cusabio Biotech Co. Ltd., Wuhan, P. R. China).

\section{Cluster of differentiation 4 and cluster of differentiation 8 molecules in jejunum}

Concentrations of CD4 and CD8 molecules in jejunal extracts were assayed colorimetrically, through the antigenantibody reaction, instrument measured absorbance in the 450nm wavelength with ELISA kits (Cusabio).

\section{RNA isolation and real-time polymerase chain reaction analysis}

Total RNA of the jejunum was isolated using Trizol according to the manufacturer's instructions and the quantity and quality were assessed by $\mathrm{OD}_{260: 280}$. DNA elimination and reverse-transcription of total RNA $(2 \mu \mathrm{g})$ was performed using the PrimeScript ${ }^{\circledR}$ RT reagent Kit with gDNA Eraser (Takara Biotechnology Co., Ltd., Dalian, China). Quantitative real-time polymerase chain reaction (RT-PCR) was performed using a BIO-Rad CFX 96 instrument and SYBR Premix Ex TagII (Tli RNaseH Plus) (Takara Biotechnology Co., Ltd., Dalian, China) with glyceraldehyde-3-phosphate dehydrogenase (GAPDH) serving as the endogenous control gene. Each $20 \mu \mathrm{L}$ realtime PCR reaction contained $10 \mu \mathrm{L}$ of SYBR Premix Ex Tag II (Tli RNaseH Plus)(2×), 0.8 $\mu \mathrm{L}$ of PCR Forward Primer $(10 \mu \mathrm{M}), 0.8 \mu \mathrm{L}$ of PCR Reverse Primer $(10 \mu \mathrm{M})$, $0.4 \mu \mathrm{L}$ of ROX Reference Dye $(50 \times), 2.0 \mu \mathrm{L}$ of the cDNA product, $6.0 \mu \mathrm{L}$ of $\mathrm{ddH}_{2} \mathrm{O}$. According to the reported mRNA sequences from GeneBank, the primers of genes related to intestinal immunity and oxidative-stress response were designed by bio-software primer premier 5.0. The primers are given in Table 2. Quantitative RT-PCR reactions for each sample were performed $\left(95^{\circ} \mathrm{C}\right.$ enzyme activation step for $30 \mathrm{~S}, 40$ cycles $95^{\circ} \mathrm{C}$ denaturation step for $5 \mathrm{~S}, 56^{\circ} \mathrm{C}$ to $63^{\circ} \mathrm{C}$ annealing/elongation step for $30 \mathrm{~S}, 95^{\circ} \mathrm{C}$ denaturation step for $10 \mathrm{~S}$, and followed by melt-curve analysis performed from $65^{\circ} \mathrm{C}$ to $95^{\circ} \mathrm{C}$, using $0.5^{\circ} \mathrm{C}$ temperature increments with $5 \mathrm{~S}$ hold in each step) in triplicate. The transcript abundance of genes was quantified and relative expression was calculated using the $2^{-\Delta \Delta C t}$ method. After normalization to GAPDH, the fold-change of each gene was then expressed relative to the average of the measurements

Table 2. Primer pairs of chicken genes related to intestinal immunity and oxidative stress

\begin{tabular}{|c|c|c|c|c|}
\hline Target gene & Accession & Sequence of primers ${ }^{2}$ & Length/bp & $\mathrm{T}_{\mathrm{A}}\left({ }^{\circ} \mathrm{C}\right)$ \\
\hline \multirow[t]{2}{*}{ GAPDH } & NM_204305 & F:5'-ACATCATCCCAGCGTCCA-3' & 189 & 58 \\
\hline & & R:5’-CATCAGCAGCAGCCTTCAC-3' & & \\
\hline \multirow[t]{2}{*}{$I L-4$} & NM_001007079 & F:5'-GAGAGGTTTCCTGCGTCAAGAT-3' & 114 & 60 \\
\hline & & R:5'-AGTGCTGGCTCTCCCAAACA-3' & & \\
\hline \multirow[t]{2}{*}{$I L-6$} & NM_204628 & F:5’-GAAATCCCTCCTCGCCAATC-3’ & 107 & 61 \\
\hline & & R:5'-CCCTCACGGTCTTCTCCATAAAC-3' & & \\
\hline \multirow[t]{2}{*}{$T N F-\alpha$} & NM_204267 & F:5'-GAAGCAGCGTTTGGGAGTG-3' & 203 & 58 \\
\hline & & R:5'-GTTGTGGGACAGGGTAGGG-3' & & \\
\hline \multirow[t]{2}{*}{$I F N-\gamma$} & NM_205149 & F:5'-GCTGACGGTGGACCTATT-3' & 198 & 56 \\
\hline & & R:5'-CACCTTCTTCACGCCATC-3' & & \\
\hline \multirow[t]{2}{*}{$N F-\kappa B P 50$} & D13719.1 & F:5'-TGCGTCTTATGTTTACTGCCTTTC-3' & 145 & 61 \\
\hline & & R:5'-CCGCTGTCCTGTCCATTCTTA-3' & & \\
\hline \multirow[t]{2}{*}{$N F-\kappa B P 65$} & D13721.1 & F:5'-CCAGGTTGCCATCGTGTTCC-3' & 179 & 63 \\
\hline & & R:5'-GCGTGCGTTTGCGCTTCT-3' & & \\
\hline
\end{tabular}

F, forward primer; R, reverse primer; GAPDH, glyceraldehyde-3-phosphate dehydrogenase; IL, interleukin; TNF, tumor necrosis factor; IFN, interferon; $\mathrm{NF}-\kappa \mathrm{B}$, nuclear factor kappa B. 
Table 3. Growth performance of broilers fed oxidized soybean oil

\begin{tabular}{|c|c|c|c|c|c|c|c|c|c|c|}
\hline \multirow{2}{*}{ Variables } & \multirow{2}{*}{ Day } & \multicolumn{6}{|c|}{ POV levels of the diets $\left(\mathrm{meqO}_{2} / \mathrm{kg}\right)$} & \multirow{2}{*}{ SEM } & \multicolumn{2}{|c|}{ p-values } \\
\hline & & 0.15 & 1.01 & 3.14 & 4.95 & 7.05 & 8.97 & & $\mathrm{~L}$ & Q \\
\hline \multirow{3}{*}{$\begin{array}{r}\text { BW } \\
(\mathrm{g})\end{array}$} & 1 & 34.33 & 34.35 & 34.32 & 34.33 & 34.33 & 34.34 & 0.01 & 0.93 & 0.55 \\
\hline & 10 & 137.12 & 134.16 & 131.71 & 130.65 & 130.99 & 131.72 & 1.84 & 0.03 & 0.03 \\
\hline & 22 & $435.37^{\mathrm{a}}$ & $433.78^{\mathrm{ab}}$ & $433.67^{\mathrm{ab}}$ & $424.56^{\mathrm{abc}}$ & $420.08^{\mathrm{bc}}$ & $426.61^{\mathrm{ab}}$ & 4.95 & 0.04 & 0.09 \\
\hline \multirow{2}{*}{$\begin{array}{l}\text { ADG } \\
\qquad(\mathrm{g} / \mathrm{bird} / \mathrm{d})\end{array}$} & $1-10$ & 11.42 & 11.09 & 10.82 & 10.70 & 10.74 & 10.82 & 0.20 & 0.03 & 0.03 \\
\hline & $1-22$ & $19.10^{\mathrm{a}}$ & $19.02^{\mathrm{ab}}$ & $19.02^{\mathrm{ab}}$ & $18.58^{\mathrm{ab}}$ & $18.37^{\mathrm{b}}$ & $18.68^{\mathrm{ab}}$ & 0.24 & 0.04 & 0.09 \\
\hline \multirow{2}{*}{$\begin{array}{l}\text { ADFI } \\
(\mathrm{g} / \mathrm{bird} / \mathrm{d})\end{array}$} & $1-10$ & $16.19^{\mathrm{a}}$ & $16.06^{\mathrm{a}}$ & $14.14^{\mathrm{b}}$ & $14.17^{\mathrm{b}}$ & $14.97^{\mathrm{ab}}$ & $14.67^{\mathrm{b}}$ & 0.44 & 0.01 & 0.09 \\
\hline & $1-22$ & 31.81 & 31.32 & 31.28 & 32.11 & 31.49 & 32.42 & 0.61 & 0.36 & 0.49 \\
\hline \multirow{2}{*}{$\begin{array}{l}\mathrm{F} / \mathrm{G} \\
(\mathrm{g} / \mathrm{g})\end{array}$} & $1-10$ & 1.42 & 1.45 & 1.31 & 1.33 & 1.40 & 1.36 & 0.04 & 0.25 & 0.24 \\
\hline & $1-22$ & 1.66 & 1.65 & 1.64 & 1.73 & 1.72 & 1.74 & 0.03 & 0.01 & 0.04 \\
\hline
\end{tabular}

POV, peroxide value; SEM, standard error of the mean; L, linear; Q, quadratic; BW, body weight; ADG, average daily gain; ADFI, average daily feed intake; F/G, feed intake/gain.

${ }^{a b c}$ Means bearing different superscripts in a row differ significantly $(\mathrm{p}<0.05)$.

made from chickens on the control diet (fresh soybean oil).

\section{Statistical analysis}

Effects of treatment were assessed by one-way analysis of variance and, when treatment effects were significant, they were partitioned using linear and quadratic contrasts, according to the SAS user guide statistics (SAS, 1996). Pen (replicate) was used as the experimental unit in the analysis of growth performance reactions and individual broiler was used as the experimental unit for all other reactions. Data satisfied Bartlett's test for homogeneity and were expressed as means. Treatment effects were considered significant if $\mathrm{p}<0.05$.

\section{RESULTS}

\section{Growth performance}

During the first $10 \mathrm{~d}$, POV levels significantly reduced ADFI (linear, $\mathrm{p}=0.01$ ) of the broilers, while it did not affect BW, ADG, and F/G of the broilers (Table 3). Effects were apparent at $\mathrm{POV}$ exceeding $3.14 \mathrm{meqO}_{2} / \mathrm{kg}$. For the entire feeding period ( 1 to $22 \mathrm{~d}$ ), POV levels significantly reduced $\mathrm{BW}$ and $\mathrm{ADG}$ (both linear, $\mathrm{p}=0.04$ ) of the broilers, while it did not affect ADFI and F/G of the broilers. The
$\mathrm{BW}$ and $\mathrm{ADG}$ were reduced at $\mathrm{POV}$ exceeding 7.05 $\mathrm{meqO}_{2} / \mathrm{kg}$.

\section{Biochemical indices in plasma}

The POV levels significantly increased the concentration in plasma of MDA (linear and quadratic, both $\mathrm{p}<0.001$ ) and reduced the activities of T-AOC (linear and quadratic, both $\mathrm{p}<0.001$ ), CAT (quadratic, $\mathrm{p}<0.001$ ) and GST (linear, $\mathrm{p}=0.03$ ), but did not affect the activity of TSOD or concentrations of immunoglobulins ( $\operatorname{IgA}$ and $\operatorname{IgG}$ ) in plasma (Table 4). The increase in MDA was apparent at POV exceeding $4.95 \mathrm{meqO}_{2} / \mathrm{kg}$ while decreases in T-AOC, CAT and GST, relative to the control diet, were apparent with $\mathrm{POV}$ at $4.95 \mathrm{meqO}_{2} / \mathrm{kg}$ or above $1.01 \mathrm{meqO}_{2} / \mathrm{kg}$.

\section{Antioxidant and immune-related indices of jejunum}

As shown in Table 5, increasing dietary POV increased the concentration in jejunal mucosa of MDA (linear and quadratic, both $\mathrm{p}<0.001)$ and reduced the activities of $\mathrm{T}$ AOC (linear, $p=0.02$, quadratic, $p<0.001$ ) and CAT (linear and quadratic, both $\mathrm{p}<0.001$ ), but did not affect the activities of T-SOD and GST. Increased mucosal MDA was apparent at $\mathrm{POV}$ exceeding $3.14 \mathrm{meqO}_{2} / \mathrm{kg}$ and the decreases in T-AOC and CAT were apparent for diets with

Table 4. Biochemical indices in plasma of broilers fed oxidized soybean oil

\begin{tabular}{|c|c|c|c|c|c|c|c|c|c|}
\hline \multirow{2}{*}{ Variables } & \multicolumn{6}{|c|}{ POV levels of the diets $\left(\mathrm{meqO}_{2} / \mathrm{kg}\right)$} & \multirow{2}{*}{ SEM } & \multicolumn{2}{|c|}{ p-values } \\
\hline & 0.15 & 1.01 & 3.14 & 4.95 & 7.05 & 8.97 & & $\mathrm{~L}$ & Q \\
\hline MDA (nmol/mL) & $3.75^{\mathrm{bc}}$ & $3.58^{\mathrm{c}}$ & $3.67^{\mathrm{c}}$ & $3.98^{\mathrm{bc}}$ & $4.67^{\mathrm{ab}}$ & $5.21^{\mathrm{a}}$ & 0.31 & 0.00 & 0.00 \\
\hline T-AOC (U/mL) & $14.03^{\mathrm{a}}$ & $11.82^{\mathrm{ab}}$ & $12.60^{\mathrm{ab}}$ & $10.44^{\mathrm{b}}$ & $11.23^{\mathrm{b}}$ & $10.50^{\mathrm{b}}$ & 0.74 & 0.00 & 0.00 \\
\hline T-SOD (U/mL) & 163.57 & 173.33 & 156.95 & 166.50 & 148.23 & 169.35 & 8.29 & 0.62 & 0.74 \\
\hline CAT $(\mathrm{U} / \mathrm{mL})$ & $56.67^{\mathrm{a}}$ & $35.21^{\mathrm{b}}$ & $33.95^{\mathrm{b}}$ & $37.13^{\mathrm{b}}$ & $39.39^{\mathrm{b}}$ & $39.86^{\mathrm{b}}$ & 4.70 & 0.12 & 0.00 \\
\hline GST (U/mL) & $157.26^{\mathrm{a}}$ & $122.28^{\mathrm{b}}$ & $134.61^{\mathrm{b}}$ & $135.48^{\mathrm{b}}$ & $128.96^{\mathrm{b}}$ & $124.00^{\mathrm{b}}$ & 7.39 & 0.03 & 0.05 \\
\hline $\operatorname{IgA}(\mu \mathrm{g} / \mathrm{mL})$ & $1,903.57$ & $1,943.49$ & $1,802.54$ & $2,050.50$ & $1,763.27$ & $2,002.30$ & 175.18 & 0.90 & 0.97 \\
\hline $\operatorname{IgG}(\mu \mathrm{g} / \mathrm{mL})$ & 543.40 & 538.90 & 508.50 & 425.25 & 456.70 & 511.25 & 83.65 & 0.54 & 0.65 \\
\hline
\end{tabular}

POV, peroxide value; SEM, standard error of the mean; L, linear; Q, quadratic; MDA, malondialdehyde; T-AOC, total antioxidant capacity; T-SOD, total superoxide dismutase, CAT, catalase; GST, glutathione S-transferase; Ig, immunoglobulin.

${ }^{a b c}$ Means bearing different superscripts in a row differ significantly $(\mathrm{p}<0.05)$. 
Table 5. Antioxidant and immune-related indices in jejunal mucosa of broilers

\begin{tabular}{|c|c|c|c|c|c|c|c|c|c|}
\hline \multirow{2}{*}{ Variables } & \multicolumn{6}{|c|}{ POV levels of the diets $\left(\mathrm{meqO}_{2} / \mathrm{kg}\right)$} & \multirow{2}{*}{ SEM } & \multicolumn{2}{|c|}{ p-values ${ }^{2}$} \\
\hline & 0.15 & 1.01 & 3.14 & 4.95 & 7.05 & 8.97 & & $\mathrm{~L}$ & Q \\
\hline MDA (nmol/mgprot) & $2.00^{\mathrm{b}}$ & $2.24^{\mathrm{b}}$ & $3.34^{\mathrm{a}}$ & $3.80^{\mathrm{a}}$ & $3.80^{\mathrm{a}}$ & $4.30^{\mathrm{a}}$ & 0.30 & 0.00 & 0.00 \\
\hline T-AOC (U/mg prot) & $1.72^{\mathrm{a}}$ & $1.42^{\mathrm{ab}}$ & $1.26^{\mathrm{bc}}$ & $1.25^{\mathrm{bc}}$ & $1.10^{\mathrm{c}}$ & $1.38^{\mathrm{bc}}$ & 0.11 & 0.02 & 0.00 \\
\hline T-SOD (U/mg prot) & 90.00 & 92.50 & 100.32 & 91.93 & 86.22 & 98.90 & 4.72 & 0.66 & 0.91 \\
\hline CAT (U/mg prot) & $47.43^{\mathrm{a}}$ & $39.10^{\mathrm{b}}$ & $38.00^{\mathrm{bc}}$ & $33.59^{\mathrm{cd}}$ & $27.08^{\mathrm{e}}$ & $31.89^{\mathrm{d}}$ & 1.79 & 0.00 & 0.00 \\
\hline GST (U/mg prot) & 117.33 & 115.18 & 137.27 & 120.38 & 105.68 & 129.59 & 11.22 & 0.88 & 0.98 \\
\hline $\operatorname{SIgA}(\mu \mathrm{g} / \mathrm{mL})$ & $4.02^{\mathrm{a}}$ & $4.26^{\mathrm{a}}$ & $3.42^{\mathrm{ab}}$ & $2.80^{\mathrm{bc}}$ & $2.68^{\mathrm{bc}}$ & $2.14^{\mathrm{c}}$ & 0.35 & 0.00 & 0.00 \\
\hline CD4 (ng/mL) & $35.40^{\mathrm{a}}$ & $38.97^{\mathrm{a}}$ & $22.57^{\mathrm{b}}$ & $22.32^{\mathrm{b}}$ & $20.86^{\mathrm{b}}$ & $21.99^{\mathrm{b}}$ & 3.93 & 0.00 & 0.00 \\
\hline CD8 (ng/mL) & $22.51^{\mathrm{ab}}$ & $23.25^{\mathrm{a}}$ & $16.53^{\mathrm{abc}}$ & $12.14^{\mathrm{c}}$ & $15.41^{\mathrm{bc}}$ & $17.84^{\mathrm{abc}}$ & 2.49 & 0.03 & 0.01 \\
\hline
\end{tabular}

POV, peroxide value; SEM, standard error of the mean; L, linear; Q, quadratic; MDA, malondialdehyde; T-AOC, total antioxidant capacity; T-SOD, total superoxide dismutase; CAT, catalase; GST, glutathione S-transferase; SIgA, secretory immunoglobulin A; CD4, cluster of differentiation 4; CD8, cluster of differentiation 8 .

${ }^{\mathrm{abc}}$ Means bearing different superscripts in a row differ significantly $(\mathrm{p}<0.05)$.

POV at or above $1.01 \mathrm{meqO}_{2} / \mathrm{kg}$. Mucosal concentrations of SIgA and CD4 molecules (linear and quadratic, all $\mathrm{p}<$ 0.001) and CD8 molecules (linear, $\mathrm{p}=0.03$, quadratic, $\mathrm{p}=$ 0.01 ) decreased as dietary POV increased, with differences from the control diet apparent at POV greater than 3.14 to $4.95 \mathrm{meqO} \mathrm{O}_{2} / \mathrm{kg}$.

\section{Relative transcript abundance in jejunum of genes related to immunity}

Increasing dietary POV level significantly increased the jejunal transcript abundance of nuclear factor kappa B (NF-

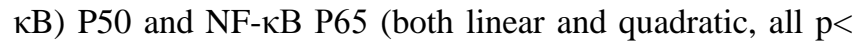
$0.001)$ and tumor necrosis factor- $\alpha$ (TNF- $\alpha$ ) and reduced the transcript abundance of interleukin (IL)-6, but did not affect those of interferon- $\gamma$ (IFN- $\gamma$ ) and IL-4 (Table 6). The increase in NF- $\kappa \mathrm{B}$ P50 and NF- $\kappa$ B P65, and TNF- $\alpha$ were apparent at $\mathrm{POV}$ exceeding 8.97 and 4.95 and 7.05 $\mathrm{meqO}_{2} / \mathrm{kg}$ respectively, but the decrease in IL-6 were apparent at $\mathrm{POV}$ exceeding $7.05 \mathrm{meqO}_{2} / \mathrm{kg}$.

\section{DISCUSSION}

As outlined in the introduction, consumption of oxidized lipids containing peroxides has an array of consequences, but possible effects on intestinal immune function, especially in young broilers were unknown. Using graded dietary levels of oxidized soybean oil, this study has clearly demonstrated deleterious effects of increasing POV on early feed intake, daily gain, intestinal oxidative stress, and redox status in plasma. Indices of intestinal mucosal immunity, SIgA and CD4 and 8, were all depressed with moderate to high POV while intestinal expression of NF-B genes increased. For most variables, the changes were proportional to POV content (linear effects) but there were exceptions where maximal changes occurred with less than the highest POV (quadratic effects).

Dietary POV, at or above quite modest levels (3.14 $\mathrm{meqO}_{2} / \mathrm{kg}$ ), negatively affected ADFI during d 1 to 10 , hence compromising $\mathrm{BW}$ and $\mathrm{ADG}$ at $\mathrm{d} 10$. For the entire starter period (d 1 to 22), ADG and final BW were similarly reduced. These results showed that the growth performance and the feed intake of the yellow broilers were impaired by the oxidized soybean oil. These findings were consistent with some earlier studies (McGill et al., 2011; Tavárez et al., 2011), but not others (Bayraktar et al., 2011; Zümrüt et al., 2011) where oxidized oil did not affect BW, ADG, or ADFI. The negative effects of the oxidized oil may stem from toxicity of lipid peroxides and reduced biological value from reduced content of linoleic acid and polyunsaturated fatty acid in favor of increased monounsaturated fatty acid

Table 6. Relative abundance of jejunal transcripts of broilers fed oxidized soybean oil

\begin{tabular}{|c|c|c|c|c|c|c|c|c|c|}
\hline \multirow{2}{*}{ Genes } & \multicolumn{6}{|c|}{ POV levels of the diets $\left(\mathrm{meqO}_{2} / \mathrm{kg}\right)$} & \multirow{2}{*}{ SEM } & \multicolumn{2}{|c|}{$p$-values ${ }^{2}$} \\
\hline & 0.15 & 1.01 & 3.14 & 4.95 & 7.05 & 8.97 & & $\mathrm{~L}$ & Q \\
\hline$N F-\kappa B$ P50 & $1.06^{\mathrm{b}}$ & $1.17^{\mathrm{ab}}$ & $0.94^{\mathrm{b}}$ & $1.30^{\mathrm{ab}}$ & $1.62^{\mathrm{ab}}$ & $1.95^{\mathrm{a}}$ & 0.26 & 0.00 & 0.01 \\
\hline$N F-\kappa B$ P65 & $1.13^{\mathrm{b}}$ & $1.14^{\mathrm{b}}$ & $1.53^{\mathrm{b}}$ & $2.79^{\mathrm{a}}$ & $1.85^{\mathrm{ab}}$ & $2.88^{\mathrm{a}}$ & 0.37 & 0.00 & 0.00 \\
\hline IFN- $\gamma$ & 0.93 & 2.02 & 1.93 & 2.08 & 2.54 & 1.78 & 0.38 & 0.15 & 0.05 \\
\hline TNF- $\alpha$ & $1.02^{\mathrm{b}}$ & $0.86^{\mathrm{b}}$ & $1.58^{\mathrm{ab}}$ & $1.18^{\mathrm{ab}}$ & $1.96^{\mathrm{a}}$ & $1.14^{\mathrm{b}}$ & 0.28 & 0.18 & 0.17 \\
\hline$I L-4$ & 1.02 & 1.06 & 1.45 & 1.29 & 1.30 & 0.66 & 0.27 & 0.53 & 0.12 \\
\hline$I L-6$ & $1.15^{\mathrm{ab}}$ & $0.69^{\mathrm{b}}$ & $1.22^{\mathrm{ab}}$ & $1.52^{\mathrm{a}}$ & $0.73^{\mathrm{b}}$ & $0.69^{\mathrm{b}}$ & 0.23 & 0.37 & 0.22 \\
\hline
\end{tabular}

POV, peroxide value; SEM, standard error of the mean; L, linear; Q, quadratic; NF- $\kappa \mathrm{B}$, nuclear factor kappa B; IFN- $\gamma$, interferon- $\gamma$, TNF- $\alpha$, tumor necrosis factor- $\alpha$; IL, interleukin.

${ }^{a b c}$ Means bearing different superscripts in a row differ significantly $(\mathrm{p}<0.05)$. 
and saturated fatty acid (Bou et al., 2005). Oxidized oil does not affect the lipid digestible energy or metabolizable energy, nor the digestibility coefficients of lipid dry matter, gross energy and ether extract (Casado et al., 2010; Zümrüt et al., 2011; Liu, 2012), but the decrease in ADFI during the first $10 \mathrm{~d}$, presumably reflecting sensory inappetence, could account for the impaired growth performance, carrying over for the whole 22-d period, though overall ADFI did not affect.

In jejunal mucosa, directly exposed to digesta, oxidized soy oil increased concentrations of MDA, an index of lipid peroxidation in tissues, indicating that lipid peroxidation and inadequate removal of reactive oxygen species prevailed in the tissue. Diets with POV at or above 3.14 meqO $\mathrm{O}_{2} / \mathrm{kg}$ provoked significant changes in the mucosa from the control diet while those of POV at or above 4.95 showed differences in plasma MDA. Similar findings have been made in swine (Ringseis et al., 2007) and broilers (Zhang et al., 2011) fed oxidized lipid. Overall, it was clear that lipid peroxidation occurred in the intestinal mucosa of animals fed oxidized soy oil.

Dietary POV clearly unbalanced the normal physiological capacity for antioxidant systems maintaining equilibrium between generation and elimination of free radicals, thus resulting in oxidative stress. This was indicated here by the decrease in T-AOC in jejunal mucosa at lower dietary POV and, at POV above $4.95 \mathrm{meqO}_{2} / \mathrm{k}$, in plasma. The decrease in T-AOC, an index of assessing redox status, indicated that the imbalance of free radical generation and elimination occurred. Also, with minimal increases in dietary POV, mucosal and plasma activities of CAT decreased as did those of plasma GST. The CAT can resolve $\mathrm{H}_{2} \mathrm{O}_{2}$ and GST can eliminate peroxide. The decrease in CAT and GST indicated that the capacity of eliminating free radicals decreased. Decreased activities of antioxidant enzymes in intestine or enterocytes with oxidized lipids have been found using various models (Ringseis et al., 2007; David et al., 2010; Awada et al., 2012) and the present study using young chickens emphasizes just how little oxidation is required to exert deleterious effects on the occurrence of intestinal oxidative stress.

The NF- $\mathrm{B}$ of intestinal epithelial cells can attenuate oxidative stress and the activation of NF- $\kappa \mathrm{B}$ indicated that oxidative stress occurred. The increases in NF- $\kappa \mathrm{B}$ P65 and NF- $\kappa$ B P50 in intestine were significant at dietary POV of 4.95 to $8.97 \mathrm{meqO}_{2} / \mathrm{kg}$. The results were consistent with other studies which oxidized oil significantly increased the concentrations of NF- $\mathrm{BB}$ in intestine (Varady et al., 2011; Awada et al., 2012). The findings further confirmed that oxidative stress occurred in the intestine of broilers.

As the most abundant and important Ig in GALTs (Fagarasan, 2008), levels of mucosal SIgA were decreased by the diets with higher POV, contrasting with the absence of any effect on plasma IgA and IgG. Oxidized oil did not affect the concentrations of $\operatorname{IgA}$ and $\mathrm{IgG}$ in plasma of pigs (Liu, 2012) but was found to decrease the effectiveness, secretion and stability, of the intestinal SIgA response (Dibner et al., 1996). Playing a major role in mucosal protection (Shale et al., 2013), T helper and T cytotoxic cells, marked by the CD4 and CD8 molecules measured here, were reduced as dietary POV increased from 3.14 $\mathrm{meqO}_{2} / \mathrm{kg}$, with maximal effects at intermediate levels of POV, hence significant quadratic responses were observed. The most striking effect was on CD8 (T cytotoxic cells), suggesting impaired capacity to respond to damaged or infected mucosal cells. Taken together, the reduced contents of SIgA, CD4, and CD8 showed that the local immune system of the jejunal mucosa was negatively affected by the oxidized soybean oil and the consequent oxidative stress.

As an important medium of immune system, cytokines of IFN- $\gamma$, TNF- $\alpha$, IL-4, and IL6 can interact with cell membrane receptors and involve in the immune response, immune regulation and inflammation (Gupta et al., 2012). Dietary POV significantly increased the transcript abundance of TNF- $\alpha$ and reduced those of IL- 6 in jejunum, but there were no linear and quadratic effects in TNF- $\alpha$ and IL-6. Dietary POV did not affect the transcript abundance of IFN- $\gamma$ and IL- 4 in jejunum. TNF- $\alpha$ responds to sepsis by IL1 and IL6 producing cells and regulates immune cells which are essential in the control of intracellular pathogens. IL-6 promotes B-Cell differentiation and the production of antibody. The IFN- $\gamma$ promotes the differentiation of $\mathrm{TH}$ cells and enhances the secretion of Ig by B cells and involves in immune stimulation and immune regulation, once IFN- $\gamma$ is produced by T lymphocytes and natural killer cells after these cells are activated by immune and inflammatory stimuli (Schoenborn and Wilson, 2007). The IL-4 promotes $\mathrm{T}$ helper 2 cell differentiation from $\mathrm{CD}^{+} \mathrm{T}$ cells and the production of $\operatorname{IgG}$ and $\operatorname{IgE}$ (Brown, 2008). The findings here indicated that the transcripts of these cytokines were not affected by the oxidized soybean oil.

\section{CONCLUSION}

The growth performance, early feed intake and the local immune system of the intestine were impaired by oxidative stress when young broilers were fed moderately oxidized soybean oil. The conclusions confirm the hypotheses and prompt further study of exactly how partially oxidized soybean oil compromised the intestinal immune system. It is recommended that oil used to increase energy content of diets for young broilers should be protected from oxidative degradation because feed intake and intestinal immunity of broilers were reduced by as little as $3.14 \mathrm{meqO}_{2} / \mathrm{kg}$ dietary 
POV even though oxidative stress was apparent at even lower levels.

\section{ACKNOWLEDGMENTS}

This work was funded by the Guangdong Provincial Natural Science Fund (project s2012010010432) and by the earmarked fund for the Modern Agro-Industry Technology Research System (CARS-42) from the Ministry of Agriculture, China. Dr W. B. Currie (Emeritus Professor, Cornell University) made suggestions on presentation.

\section{CONFLICT OF INTEREST}

We certify that there is no conflict of interest with any financial organization regarding the material discussed in the manuscript.

\section{REFERENCES}

Awada, M., C. O. Soulage, A. Meynier, C. Debard, P. Plaisancié, B. Benoit, G. Picard, E. Loizon, M. A. Chauvin, M. Estienne, N. Peretti, M. Guichardant, M. Lagarde, C. Genot, and M. C. Michalski. 2012. Dietary oxidized n-3 PUFA induce oxidative stress and inflammation: role of intestinal absorption of 4-HHE and reactivity in intestinal cells. J. Lipid Res. 53:2069-2080.

Bayraktar, H., Ö. Altan, Z. Açkgöz, Ş. H. Baysal, and Ç. Şeremet. 2011. Effects of oxidised oil and vitamin $E$ on performance and some blood traits of heat-stressed male broilers. S. Afr. J. Anim. Sci. 41:288-296.

Boler, D. D., D. M. Fernández-Dueñas, L. W. Kutzler, J. Zhao, R. J. Harrell, D. R. Campion, F. K. Mckeith, J. Killefer, and A. C. Dilger. 2012. Effects of oxidized corn oil and a synthetic antioxidant blend on performance, oxidative status of tissues, and fresh meat quality in finishing barrows. J. Anim. Sci. 90:5159-5169.

Bou, R., R. Codony, M. D. Baucells, and F. Guardiola. 2005. Effect of heated sunflower oil and dietary supplements on the composition, oxidative stability, and sensory quality of dark chicken meat. J. Agric. Food Chem. 53:7792-7801.

Brown, M. A. 2008. IL-4 production by T cells: You need a little to get a lot. J. Immunol. 181:2941-2942.

Casado, C., V. J. Moya, C. Fernández, J. J. Pascual, E. Blas, and C. Cervera. 2010. Diet digestibility in growing rabbits: Effect of origin and oxidation level of dietary fat and vitamin $\mathrm{E}$ supplementation. World Rabbit Sci. 18:57-63.

David, R. O., S. Bastida, A. Schultz, L. G. Torres, M. J. GonzálezMuñoz, F. J. Sánchez-Muniz, and J. Benedí. 2010. Fasting status and thermally oxidized sunflower oil ingestion affect the intestinal antioxidant enzyme activity and gene expression of male wistar rats. J. Agric. Food Chem. 58:2498-2504.

Dibner, J. J., C. A. Atwell, M. L. Kitchell, W. D. Shermer, and F. J. Ivey. 1996. Feeding of oxidized fats to broilers and swine: Effects on enterocyte turnover, hepatocyte proliferation and the gut associated lymphoid tissue. Anim. Feed Sci. Technol. 62:113.

Fagarasan, S. 2008. Evolution, development, mechanism and function of IgA in the gut. Curr. Opin. Immunol. 20:170-177.

Gupta, A., A. Kaul, A. G. Tsolaki, U. Kishore, and S. Bhakta. 2012. Mycobacterium tuberculosis: Immune evasion, latency and reactivation. Immunobiology 217:363-374.

Hidalgo, F. J. and R. Zamora. 2004. Strecker-type degradation produced by the lipid oxidation products 4,5-epoxy-2-alkenals. J. Agric. Food Chem. 52:7126-7131.

ISO. 3960. 2007. Animal and vegetable fats and oils -determination of peroxide value -- iodometric (visual) endpoint determination. http://www.iso.org/iso/iso_catalogue/ catalogue_ics/catalogue_ics_browse.htm?ICS1 $=67 \&$ ICS2 $=200$ \&ICS3=10, Accessed July 15, 2007.

Liu, P. 2012. Biological Assessment and Methods to Evaluate Lipid Peroxidation When Feeding Thermally-oxidized Lipids to Young Pigs. Ph.D Thesis, The Graduate School of the University of Minnesota. Minneapolis, MN, USA.

Mcgill, J., E. Mcgill, A. Kamyab, and J. D. Firman. 2011. Effect of high peroxide value fats on performance of broilers in a normal immune state. Int. J. Poult. Sci. 10:241-246.

NRC. 1994. Nutrient Requirements of Poultry. Washington, DC, USA.

Oarada, M., T. Majima, T. Miyazawa, K. Fujimoto, and T. Kaneda. 1989. The effect of dietary autoxidized oils on immunocompetent cells in mice. Biochim. Biophys. Acta. 1012:156-160.

Ringseis, R., N. Piwek, and K. Eder. 2007. Oxidized fat induces oxidative stress but has no effect on NF- $\mathrm{BB}$-mediated proinflammatory gene transcription in porcine intestinal epithelial cells. Inflamm. Res. 56:118-125.

Rosario, Z. and F. J. Hidalgo. 1994. Modification of lysine amino groups by the lipid peroxidation product 4,5 (e)-epoxy-2 (e)heptenal. Lipids 29:243-249.

SAS. 1996. SAS User's Guide Statistics. SAS Institute. Cary, NC, USA.

Schoenborn, J. R. and C. B. Wilson 2007. Regulation of interferon-gamma during innate and adaptive immune responses. Adv. Immunol. 96:41-101.

Scurtu, I., S. Andrei, C. Catoi, A. I. Baba, and F. Bolos. 2003. Preliminary data regarding the influence of oxidized oil administration on antioxidant enzymes' activity in broiler chickens. In: 2nd International Symposium on Prospects for the 3rd Millennium Agriculture. Cluj Napoca, Romania.

Shafaeizadeh, S., J. Jamalian, A. A. Owji, L. Azadbakht, R. Ramezani, N. Karbalaei, A. Rajaeifard, and N. Tabatabai. 2011. The effect of consuming oxidized oil supplemented with fiber on lipid profiles in rat model. J. Res. Med. Sci. 16:1541-1549.

Shale, M., C. Schiering, and F. Powrie 2013. CD4 ${ }^{+}$T-cell subsets in intestinal inflammation. Immunol. Rev. 252:164-182.

Takahashi, K. and Y. Akiba. 1999. Effect of oxidized fat on performance and some physiological responses in broiler chickens. Jpn. J. Poult. Sci. 36:304-310.

Tavárez, M. A., D. D. Boler, K. N. Bess, J. Zhao, F. Yan, A. C. Dilger, F. K. Mckeith, and J. Killefer. 2011. Effect of antioxidant inclusion and oil quality on broiler performance, meat quality, and lipid oxidation. Poult. Sci. 90:922-930.

Varady J., K. Eder, and R. Ringseis. 2011. Dietary oxidized fat activates the oxidative stress-responsive transcription factors $\mathrm{NF}-\kappa \mathrm{B}$ and Nrf2 in intestinal mucosa of mice. Eur. J. Nutr. 50:601-609. 
Wijeratne, S. S. K. and S. L. Cuppett. 2007. Oxidative stress induced by lipid hydroperoxides in the intestine. Agro. Food Idustry Hi-Tech. 18:27-29.

Zhang, W. G, S. Xiao, E. J. Lee, and D. U. Ahn. 2011. Consumption of oxidized oil increases oxidative stress in broilers and affects the quality of breast meat. J. Agric. Food Chem. 59:969-974.
Zümrüt, A., H. Bayraktar, O. Altan, S. T. Akhisaroglu, F. Kırkpınar, and Z. Altun. 2011. The effects of moderately oxidised dietary oil with or without vitamin E supplementation on performance, nutrient digestibility, some blood traits, lipid peroxidation and antioxidant defence of male broilers. J. Sci. Food Agric. 91: 1277-1282. 